\title{
SEBERAPA BESAR KUALITAS PRODUK MEMPENGARUHI KEPUTUSAN PEMBELIAN SEPEDA MOTOR HONDA BEAT (SENSUS PADA KOMUNITAS HONDA BEAT PURWAKARTA)
}

\author{
Reminta Lumban Batu', Fitri Nur Afifah ${ }^{2}$, Hanifah Baihaqi ${ }^{3}$, Indri Pramesti ${ }^{4}$ \\ Universitas Singaperbangsa Karawang
}

reminta.lumban@fe.unsika.ac.id

\begin{abstract}
Honda is one of the companies that issued a lot of vehicle products, one of which was Honda Beat. This study discusses how much influence the quality of the product has on the purchase decision of the matic Honda beat motorbike at the Honda Beat Community in Purwakarta. The reason the author adopted this title as research material was due to the phenomenon of Honda beat motorbike users who continued to be in the number one position of Honda motorcycle sales. The methodology used in this research was descriptive and verification method with a quantitative approach. The purpose of this research is to find out the description and measure how much influence the quality of the product on the purchase decisions of Honda Beat motorcycles.
\end{abstract}

Keywords: Honda,product quality, purchasing decision

\begin{abstract}
ABSTRAK
Honda merupakan salah satu perusahan yang mengeluarkan banyak produk kendaraan, salah satunya ialah Honda Beat. Penelitian ini membahas seberapa besar pengaruh kualitas produk terhadap keputusan pembelian motor matic Honda beat pada Komunitas Honda Beat di Purwakarta. Alasan penulis mangangkat judul ini sebagai bahan penelitian ialah dikarenakan fenomena pengguna motor Honda beat yang terus berada pada urutan nomor satu penjualan motor Honda. Metodologi yang digunakan dalam penelitian ini merupakan metode deskriptif dan verifikatif dengan pendekatan kuantitatif. Tujuan penelitian ini dilakukan ialah untuk mengetahui gambaran dan mengukur seberapa besar pengaruh kualitas produk terhadap keputusan pembelian motor Honda Beat.
\end{abstract}

Kata Kunci: Honda, keputusan pembelian, kualitas produk

\section{PENDAHULUAN}

Indonesia memiliki jumlah penduduk yang sangat besar. Badan Pusat Statistik (BPS) mencatat bahwa jumlah penduduk di Indonesia pada Tahun 2018 dapat mencapai 266.297.712 jiwa yang menjadikan Indonesia sebagai negara dengan jumlah penduduk terbanyak ke empat di dunia. (www.bps.go.id, diakses pada tanggal 24 Oktober 2018, pukul 09.53; www.finance.detik.com, diakses pada tanggal 24 Oktober 2018, pukul 10.03). Tingginya jumlah penduduk di Indonesia menjadikannya sebagai pasar potensial bagi perusahaan industri transportasi, (Kristian, Denny, Rita, 2016).

Sepeda motor merupakan salah satu jenis alat transportasi yang digunakan untuk memudahkan aktivitas sehari-sehari ataupun untuk perjalanan jauh. Masyarakat di Indonesia dianggap lebih memilih menggunakan sepeda motor dibandingkan dengan mobil ataupun alat transportasi lainnya, hal tersebut dinilai lebih praktis dibawa kemana mana karena ukurannya yang lebih kecil dari pada mobil, hal ini juga mudahkan masyarakat Indonesia dalam menerjang kemacetan yang sangat sering terjadi terutama dikota-kota besar. Setiap perusahaan industry transportasi di Indonesia saling berlomba untk menghasilkan keunggulan yang terbaik dari produkproduknya segingga dapat bersaing dipasar indutri transportasi. Hal tersebut dapat membantu suatu perusahaan menacapi top leader penjualan sepeda motor matic. 


\section{Reminta Lumban Batu, Fitri Nur Afifah,

Kemajuan industri sepeda motor di Indonesia tentu didukung oleh beberapa fakor sehingga konsumen dapat memengaruhi keputusan pembelian konsumen. Beberapa faktor yang mempengaruhi keputusan pembelian antara lain adalah kualitas produk, persepsi harga, citra merek, dan promosi.

Kualitas produk saat ini sangat diperhatikan oleh konsumen sehingga perusahaan dituntut untuk menawarkan produk yang berkualitas tinggi dan mempunyai nilai lebih yang membuat produk tampak berbeda dengan pesaing sehingga konsumen memiliki minat untuk membeli produk tersebut. Dengan meningkatkan kualitas produk tentu akan semakin banyak konsumen yang tertarik membeli produk tersebut, hal ini dapat menjadikan sebuat perusahaan industry sepeda motor tidak terkalahkan oleh pesaingnya. Setiap konsumen tentu menginginkan kualitas produk yang terbaik pada produk-produk yang telah dibelinya, hal tersebut yang menjadikan setiap konsumen puas membeli produk tersebut, (Puger Harjuno, 2018). Sepeda motor matic (automatic) menjadi salah satu sepeda motor favorit bagi masyarakat Indonesia. Perusahaan Honda adalah salah satu perusahaan otomotif dari banyaknya perusahaan otomotif ternama didunia yang masuk ke Indonesia dan dibawah naungan PT Astra Honda Motor (AHM) yang merupakan produsen sepeda motor terbesar yang di Indonesia, (www.merdeka.com, diakses pada tanggal 24 Oktober 2018, pukul 17.53).

Fenomena yang terjadi saat ini adalah Honda Beat selalu menjadi andalan penjualan sekutermatic, hal ini dapat dilihat bahwa kendaraan yang diluncurkan merek Honda ini sangat diminati masyarakat dibandingkan sekutermatic lainnya. Perusahaan harus berusaha menciptakan citra merek di masyarakat tentang kualitas produknya yang nyaman dan aman agar mempunyai keunggulan kompetitif di bidangnya. Kualitas produk berpengaruh terhadap citra merek yang akan tetap memegang peranan penting terhadap keputusan pembelian konsumen. Kualitas produk yang sesuai dengan harapan dari konsumen akan memberikan stimulus kepada konsumen sehingga konsumen tertarik untuk melakukan pembelian produk. Memiliki image yang baik di mata masyarakat akan menjadi konsekuensi dari pembentukan citra yang baik pula. Istijanto mengemukakan bahwa perusahaan yang memiliki citra atau reputasi yang baik akan mendorong konsumen membeli produk yang ditawarkan. Hal ini membuktikan bahwa citra merek dan reputasi sangat berpengaruh dalam keputusan pembelian konsumen, (Puger Harjuno, 2018; Bagas Rifki Wicaksono, 2016). Berdasarkan uraian pendahuluan diatas, maka dilakukan penelitian yang berkaitan dengan penjualan top brand kualitas produk terhadap keputusan pembelian motor matic Honda Beat, sehingga penelitian mengambil judul "Pengaruh Kualitas Produk Terhadap Keputusan Pembelian Sepeda Motor Matic Honda Beat”.

\section{TINJAUAN PUSTAKA}

\section{Konsep Pemasaran}

Definisi pemasaran menurut America Marketing Association (AMA), dalam (Keller, 2016), "Marketing is the activity, set of institutions, and processes for creating, communicating, delivering, and exchanging offerings that have value for customers, clients, partners, and society at large." Arti dari definisi tersebut, pemasaran adalah suatu fungsi organisasi dan serangkaian proses untuk menciptakan, mengkomunikasikan, menghantarkan dan memberikan nilai pelanggan yang unggul.

\section{Kualitas Produk}

Kualitas produk merupakan segala sesuatu yang dapat ditawarkan ke pasar karena dinilai memiliki kelebihan tersendiri untuk mendapatkan perhatian, dibeli, digunakan, atau dikonsumsi agar dapat memuaskan keinginan dan kebutuhan konsumen, sehingga konsumen melakukan keputusan pembelian, (Kotler dan Armstrong, 2014).

\section{Keputusan Pembelian}

Keputusan pembelian adalah "Operational definition of the purchase decision can be defined that every consumer 
has 5 stages of decision making, especially in complex decision situations: recognizing the problem, research to gather information, evaluate options, and make decisions about purchases, behavior after purchase. Purchasing process is started much before the actual time of purchase and its consequences continue until long time after the purchase", (Doostar, Kazemi, \& Kazemi, 2012). Dari KERANGKA PEMIKIRAN penjelasan tersebut dapat diambil kesimpulan bahwa setiap konsumen memiliki lima tahapan dalam pengambilan keputusan, terutama dalam pengambilan keputusan yang kompleks. Lima tahapan tersebut ialah, mengenali masalah, riset untuk mengumpulkan informasi, mengevaluasi opsi, membuat keputusan tentang pembelian, dan perilaku setelah pembelian.

\section{METODE PENELITIAN}

Pada penelitian yang dilakukan penulis, metode penelitian yang digunakan adalah metode deskriptif dan verifikatif dengan pendekatan kuantitatif. Variable yang terdapat dalam penelitian ini yaitu variabel bebas dan variable terikat. Variabel Dependen dalam penelitian ini merupakan Keputusan Pembelian (Y), dimana variabel tersebut merupakan variabel utama yang menjadi faktor yang berlaku dalam penelitian. Variabel 
Independen dalam penelitian ini adalah Kualitas Produk (X).Peneliti menggunakan skala pengukuran guna menghasilkan data kuantitatif yang akurat dan tepat. Secara umum teknik dalam pemberian skor yang digunakan dalam kuesioner penelitian ini adalah teknik skala Likert. Penelitian ini juga menggunakan skala ordinal dalam kuesioner penelitiannya. Target populasi dari penelitian ini adalah seluruh Komunitas Honda Beat di Purwakarta. Pengambilan sampel ini harus dilakukan sedemikian rupa sehingga sampel dapat mewakili (Representative) dan menggambarkan populasi sebenarnya. Metode pengambilan sampel yang digunakan pada penelitian ini menggunakan metode NonProbability sampling. Pada penelitian ini, kami memutuskan untuk mengambil sampel sebanyak 60 sampel.

Jenis nonprobability sampling dalam pengambilan sampel penelitian ini adalah sampling jenuh atau sering disebut juga sensus. Dimana peneliti akan mengambil sampel dalam penelitian ini sejumlah sampel dengan kriteria, yaitu usia minimal 17 tahun, merupakan Komunitas Honda Beat. Pengujian validitas dan reliabilitas pada penelitian ini dilaksanakan dengan menggunakan alat bantu software komputer program yaitu IBM SPSS Statistics 24 for windows64. Dalam penelitian ini tipe validitas yang digunakan ialah validitas konstruk, yaitu menentukan validitas dengan cara mengkorelasikan antar skor yang didapatkan berdasarkan masing-masing item yang berupa sejumlah pertanyaan dengan skor total keseluruhannya.

Dalam pengujian ini rumus yang digunakan ialah sebagai berikut:

$r_{X Y}=\frac{n(\Sigma X)(\Sigma Y}{\sqrt{\left[n\left(\Sigma X^{2}-(\Sigma X)^{2}\right]\left[n\left(\Sigma Y^{2}-(\Sigma Y)^{2}\right]\right.\right.}}$

(Sugiyono, 2013:248)

Dalam penelitian ini teknik perhitungan yang digunakan untuk menganalisa tes ialah teknik korelasi biasa, yaitu korelasi dengan menggunakan skor-skor tes yang telah divalidasikan dengan skor-skor tes tolak ukurnya berdasarkan responden yang sama. Setelahnya perlu diuji apakah koefisien validitas yang digunakan signifikan terhadap taraf signifikan tertentu, artinya adanya koefesien validitas tersebut bukan karena faktor kebetulan melainkan karena sudah teruji kebenarannya, hal tersebut diuji dengan menggunakan rumus uji t sebagai berikut:

$$
t=\frac{r \sqrt{n-2}}{\sqrt{1-r^{2}}}
$$

(Sugiyono, 2010)

Setelah setiap item diuji kevaliditasannya menggunakan alat bantu software komputer program IBM SPSS Statistics 24 for windows64 maka, didapatkan perhitungan yang menyatakan bahwa setiap item variabel yang digunakan dalam penelitian ini dinyatakan valid karena nilai r-hitung > rtabel. Perhitungan reliabilitas dalam pada penelitian ini menggunakan rumus Cronbach Alpha. Rumus Alpha yang digunakan dalam mencari nilai reliabilitas instrumen yang skornya bukan 1 dan 0 , seperti angket, kuesioner atau soal bentuk uraian. Jumlah varian butir dapat dicari dengan cara mencari nilai varian tiap butir, kemudian jumlahkan, seperti berikut ini :

$r_{11}=\left[\frac{k}{k-1}\right]\left[\frac{1-\sum \sigma b^{2}}{\sigma_{1}^{2}}\right]$

Sumber : Husein Umar (2009:170)

Berdasarkan hasil perhitungan uji reliabilitas dengan menggunakan alat bantu software komputer program IBM SPSS Statistics 24 for windows64 maka, setiap variabel yang digunakan dalam penelitian ini dinyatakan reliabel karena nilai alpha>r-tabel. Dalam pelaksanaan pengujian hipotesis metode yang dilakukan adalah metode dengan menggunakan analisis jalur (path analysis).

Dalam mengkategorikan atau mengelompokkan hasil perhitungan, maka digunakan kriteria penafsiran dengan persentase yang diambil mulai dari $0 \%$ sampai dengan $100 \%$. Penelitian ini menggunakan 
teknik analisis data yang dipergunakan untuk mengetahui suatu hubungan korelatif dalam penelitian ini dengan menggunakan teknik SEM (Structural Equation Modeling) berbasis component atau variance yang terkenal dengan Partial Least Square (PLS) sebagai alat bantunya, (Imam Ghozali, 2014).

\section{HASIL DAN PEMBAHASAN}

\section{Profil Honda Beat}

Honda beat pertama kali diluncurkan pada tahun 2008 yang sejak saat peluncurannya sudah banyak peminat nya hingga saat ini. Penjualan sepeda motor Honda Beat juga tidak hanya laris didalam negeri tetapi juga diluar negeri, hal ini dapat dilihat dari berbagai keunggulan desain, ketahanan serta performa dan masih banyak lagi kelebihan dari sepeda motor Honda Beat yang menjadikan produk ini diminati pasar motor di ASEAN. Sejak bulan Mei 2015 hingga bulan desember 2015, sepeda motor Honda Beat berjenis sekuter matic ini telah diekspor ke berbagai negara salah satunya ialah Filipina dengan pengiriman 18.496 unit. Dalam setiap tahun nya Honda Beat diharapkan terus memenuhi kebutuhan pecinta motor skutik di pasar internasional.

\section{Profil Komunitas Honda Beat Purwakarta}

Komunitas Beat Purwakarta dibentuk pada tanggal 8 Agustus 2017 yang diketuai oleh Adit Nurfarid. Komunitas ini dibentuk karena memiliki hobi yang sama yaitu, sama sama ingin membuat komunitas yang baik, taat aturan serta dapat melepaskan penat mereka dengan touring bersama. Komunitas Beat Purwakarta melakukan touring setidaknya 1 2 kali sebulan. Touring biasanya dilakukan pada awal bulan atau akhir bulan menyesuaikan mereka yang sebagian bekerja. Anggota komunitas ini $80 \%$ belum menikah dan 20\% sudah menikah. Mereka mempunya visi misi "hade kubabaturan alus $\mathrm{ku}$ duduluran'. komunitas ini berjumlah 60 orang diantaranya laki-laki 39 orang dan perempuan 21 orang.

\section{Analisis Verifikatif \\ Pengujian Outer Model}

Pengujian model pengukuran untuk menilai validitas dan reliabilitas model yang dilakukan dengan Convergent Validity, Composite Variabel dan Average Variace Extracted (AVE).

\section{Convergent Validity}

Untuk menguji convergent validity digunakan nilai outer loading atau loading factor. Suatu indicator yang terdapar dalam penelitian ini dinyatakan memenuhi convergent validity dapat dikatakan dalam kategori baik apabila nilai outer loading $>0,7$. Berikut ini adalah nilai outer loading dari masing-masing indikator yang terdapat pada variabel penelitian :

Tabel 1. Convergent Validity

\begin{tabular}{|l|l|l|l|l|}
\hline Indikator & $(\mathrm{O})$ & $\begin{array}{l}(\mathrm{M} \\
)\end{array}$ & $\begin{array}{l}(\mathrm{STD} \\
\mathrm{EV})\end{array}$ & $\begin{array}{l}(\mathrm{O} / \mathrm{STD} \\
\mathrm{EV})\end{array}$ \\
\hline $\begin{array}{l}\text { D1 <- kualitas } \\
\text { produk }\end{array}$ & $\begin{array}{l}0,8 \\
68\end{array}$ & $\begin{array}{l}0,8 \\
69\end{array}$ & 0,023 & 38,262 \\
\hline $\begin{array}{l}\text { D2 <- kualitas } \\
\text { produk }\end{array}$ & $\begin{array}{l}0,7 \\
90\end{array}$ & $\begin{array}{l}0,7 \\
85\end{array}$ & 0,059 & 13,326 \\
\hline $\begin{array}{l}\text { D3 <- kualitas } \\
\text { produk }\end{array}$ & 0,7 & 0,7 & 0,052 & 14,723 \\
64 & 75 & & \\
\hline $\begin{array}{l}\text { D4 <- kualitas } \\
\text { produk }\end{array}$ & 0,8 & 0,8 & 0,028 & 30,546 \\
54 & 52 & & \\
\hline $\begin{array}{l}\text { D5 <- kualitas } \\
\text { produk }\end{array}$ & 0,7 & 0,7 & 0,059 & 13,201 \\
\hline $\begin{array}{l}\text { D6 <- kualitas } \\
\text { produk }\end{array}$ & $\begin{array}{l}0,6 \\
96\end{array}$ & $\begin{array}{l}0,6 \\
97\end{array}$ & 0,063 & 11,036 \\
\hline $\begin{array}{l}\text { D7 <- keputusan } \\
\text { pembelian }\end{array}$ & $\begin{array}{l}0,7 \\
93\end{array}$ & $\begin{array}{l}0,7 \\
97\end{array}$ & 0,042 & 18,748 \\
\hline $\begin{array}{l}\text { D8 <- keputusan } \\
\text { pembelian }\end{array}$ & 0,6 & 0,6 & 0,061 & 11,041 \\
75 & 97 & & \\
\hline $\begin{array}{l}\text { D9 <- keputusan } \\
\text { pembelian }\end{array}$ & 0,7 & 0,7 & 0,074 & 10,044 \\
46 & 65 & & \\
\hline $\begin{array}{l}\text { D10<- keputusan } \\
\text { pembelian }\end{array}$ & 0,7 & 0,7 \\
57 & 63 & 0,049 & 15,424 \\
\hline $\begin{array}{l}\text { D11 <- keputusan } \\
\text { pembelian }\end{array}$ & 0,8 & 0,8 \\
09 & 01 & 0,046 & 17,442 \\
\hline
\end{tabular}

Sumber : Hasil Pengolahan Data, 2018

Berdasarkan data dalam Tabel 1 di atas, dapat diketahui bahwa dari masing-masing indikator yang terdapat dalam variabel penelitian ini sebagian besar banyak yang memiliki nilai outer loading > 0,7, namun masih terdapat dua indikator dalam variabel penelitian ini yang masih memiliki nilai outer 
loading < 0,7. Dalam model PLS memenuhi convergent validity dapat dikatakan valid apabila nilai loading 0.5 hingga 0,6 (Ghozali, 2011). Berdasarkan data di atas menunjukkan bahwa tidak ada indikator dalam variabel penelitian ini yang memiliki nilai outer loading di bawah 0,5 , sehingga semua indikator dalam variabel penelitian ini dinyatakan layak atau valid untuk digunakan sebagai bahan penelitian dan juga dapat digunakan untuk analisis lebih lanjut.

\section{Discriminant Validity}

Discriminant validity menjelaskan kemampuan setiap indikator dalam membuat pembedaan diantara konstruknya dengan konstruk yang lainnya. Dalam penelitian ini uji discriminant validity menggunakan nilai cross loading sebagai acuannya. Suatu indikator dalam variable penelitian ini dinyatakan dapat memenuhi discriminant validity apabila nilai cross loading indikator yang tedapat pada variabelnya merupakan nilai yang terbesar jika dibandingkan pada variabel lainnya. Berikut ini adalah nilai cross loading masing-masing indikator yang terdapat dalam variabel penelitian ini :

Tabel 2. Discriminant validity

\begin{tabular}{|l|l|l|}
\hline Indikator & $\begin{array}{l}\text { keputusan } \\
\text { pembelian }\end{array}$ & kualitas produk \\
\hline D1 & 0,697 & 0,868 \\
\hline D2 & 0,735 & 0,790 \\
\hline D3 & 0,597 & 0,764 \\
\hline D4 & 0,714 & 0,854 \\
\hline D5 & 0,671 & 0,779 \\
\hline D6 & 0,601 & 0,696 \\
\hline D7 & 0,793 & 0,704 \\
\hline D8 & 0,675 & 0,538 \\
\hline D9 & 0,746 & 0,655 \\
\hline D10 & 0,757 & 0,676 \\
\hline D11 & 0,809 & 0,623 \\
\hline
\end{tabular}

Sumber : Hasil Pengolahan Data, 2018

Berdasarkan sajian data pada Tabel 2 maka dapat diketahui bahwa masing-masing indikator yang terdapat pada variabel penelitian ini memiliki nilai cross loading terbesar pada variabel yang dibentuknya jika dibandingkan dengan nilai cross loading yang terdapat pada variabel lainnya. Berdasarkan hasil yang telah diperoleh tersebut, maka dapat dinyatakan bahwa indikator-indikator yang terdapat dan digunakan dalam penelitian ini dinyatakan telah memiliki discriminant validity yang baik dan dapat dipertanggung jawabkan kebenarannya dalam menyusun setiap variabelnya masing-masing.

Average Variant Extracted (AVE)

AVE yang digunakan dalam penelitian ini menggambarkan rata-rata varians atau diskriminan yang telah diekstrak pada setiap indikatornya, sehingga kemampuan setiap masing-masing item yang digunakan dalam membagi pengukuran dengan yang lainnya dapat diketahui nilainya. Besarnya nilai average variant extracted (AVE) yang digunakan dalam penelitian ini untuk masingmasing indikator harus memenuhi persyaratan yaitu nilainya harus $>0,5$ untuk model yang baik dan benar, (Ghozali, 2011).

Tabel 3. Average Variant Extracted (Ave)

\begin{tabular}{|l|l|}
\hline Indikator & $\begin{array}{l}\text { Average Variance } \\
\text { Extracted (AVE) }\end{array}$ \\
\hline $\begin{array}{l}\text { Keputusan } \\
\text { Pembelian }\end{array}$ & 0,574 \\
\hline Kuaitas Produk & 0,630 \\
\hline \multicolumn{2}{|l|}{ Sumber : Hasil Pengolahan Data, 2018 }
\end{tabular}

Berdasarkan sajian data dalam Tabel 3 dapat diketahui bahwa nilai AVE variabel kualitas produk dan keputusan pembelian > 0,5 . Dengan demikian indikator - indikator yang terdapat pada masing - masing konstruk telah dinyatakan valid dengan item yang lain dalam satu pengukuran yang sama.

\section{Composite Reliability}

Composite Reliability merupakan bagian yang digunakan untuk menguji nilai reliabilitas indikator-indikator pada suatu variabel. Suatu variabel dapat dinyatakan memenuhi composite reliability apabila memiliki nilai composite reliability > 0,6 ,(Ghozali, 2011). Berikut ini adalah nilai composite reliability dari masing-masing variabel yang digunakan dalam penelitian ini: 
Tabel 4. Composite Reliability

\begin{tabular}{|l|l|}
\hline Variabel & Composite Reliability \\
\hline Keputusan Pembelian & 0,870 \\
\hline Kuaitas Produk & 0,910 \\
\hline
\end{tabular}

Sumber : Hasil Pengolahan Data, 2018

Berdasarkan sajian data pada Tabel 4 dapat diketahui bahwa nilai composite reliability semua variabel penelitian > 0,6. Hasil perhitungan tersebut menunjukkan bahwa masing-masing variabel dinyatakan telah memenuhi composite realibility sehingga dapat disimpulkan bahwa keseluruhan variabel memiliki tingkat realibilitas yang tinggi.

\section{Uji Inner Model atau Uji Model Struktural}

Uji inner model dan uji model struktual dalam penelitian ini digunakan untuk mengevaluasi hubungan antar konstruk laten seperti yang telah dihipotesiskan sebelumnya dalam penelitian, Berdasarkan hasil output PLS yang telah dibuat didapatkan gambar sebagai berikut:

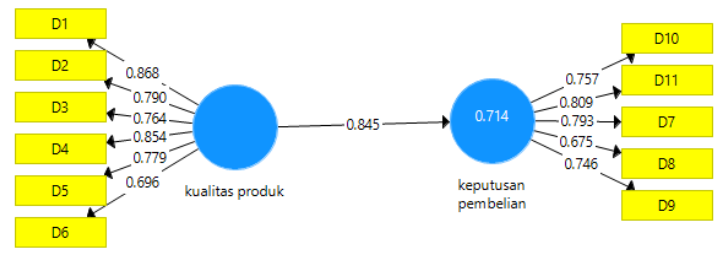

Gambar 1. Model Penelitian PLS

\section{Pengujian Hipotesis}

Berdasarkan olah data yang telah dilakukan, hasilnya dapat digunakan untuk menjawab hipotesis pada penelitian ini. Uji hipotesis pada penelitian ini dilakukan dengan melihat nilai $T$-Statistics dan nilai $P$-Values. Hipotesis penelitian dapat dinyatakan diterima apabila nilai P-Values $<0,05$.

Tabel 5. Uji Hipotesis

\begin{tabular}{|l|l|l|l|l|}
\hline $\begin{array}{l}\text { Hipote } \\
\text { sis }\end{array}$ & Pengaruh & $\begin{array}{l}T- \\
\text { Statisti } \\
\text { cs }\end{array}$ & $\begin{array}{l}P \text { - } \\
\text { Valu } \\
\text { es }\end{array}$ & Hasil \\
\hline H1 & $\begin{array}{l}\text { Kualitas } \\
\text { Produk } \\
\text { =>Keputu } \\
\text { san }\end{array}$ & 22,761 & $\begin{array}{l}0,00 \\
0\end{array}$ & $\begin{array}{l}\text { Diteri } \\
\text { ma }\end{array}$ \\
\hline
\end{tabular}

\begin{tabular}{|l|l|l|l|l|}
\hline & Pembelian & & & \\
\hline
\end{tabular}

Sumber : Hasil Pengolahan Data, 2018

Berdasarkan sajian data pada Tabel 5. dapat diketahui bahwa hipotesis yang diajukan dalam penelitian ini, dapat diterima karena pengaruh yang ditunjukkan memiliki nilai $P$ Values $<0,05$. Sehingga dapat dinyatakan variabel independen ke dependennya memiliki pengaruh yang signifikan.

\section{SIMPULAN}

Berdasarkan hasil penelitian yang telah dilakukan menggunakan analisis deskriptif dan verifikatif maka berdasarkan penelitian tersebut dapat diambil kesimpulan sebagai berikut:

1. Gambaran variabel kualitas produk diukur melalui dimensi perfomance, aesthetics, features, conformance, reliability, dan durability. Dimensi yang memperoleh rata-rata skor tertinggi adalah perfomance sedangkan dimensi yang memperoleh rata-rata skor terendah adalah features.

2. Gambaran variabel keputusan pembelian diukur melalui dimensi pilihan produk, pilihan merek, pilihan penyalur, waktu pembelian, dan metode pembayaran. Dimensi yang memperoleh rata-rata skor tertinggi adalah pilihan produk dan metode pembayaran sedangkan dimensi yang memperoleh rata-rata skor terendah adalah pilihan merek.

3. Terdapat pengaruh positif antara kualitas produk terhadap keputusan pembelian sepeda motor Honda Beat sebesar $71,4 \%$ dan sisanya $28,6 \%$ dipengaruhi variabel lain diluar penelitan.

\section{DAFTAR PUSTAKA}

Bagas Rifki Wicaksono, 2016. (2016). PENGARUH KUALITAS PRODUKTERHADAPKEPUTUSAN PEMBELIAN LAYANAN INTERNETYANGDIMEDIASI 
OLEHMINAT BELI, 45-46.

Dimas Ogie Taruna, 2018. (2018). Strata, Program Studi Ekonomi, Jurusan Manajemen.

Doostar, M., Kazemi, M. A. I., \& Kazemi, R. A. I. (2012). Impact of Brand Equity on Purchase Decision of Final Consumer Focusing on Products with Low Mental Conflict. Journal of Basic and Applied Scientific Research, 2(10), 10137-10144.

Keller, K. L. (2016). Marketing Management. https://doi.org/10.4324/9780203357262

Kristian, Denny, Rita, W. (2016). Denny Kristian, Rita Widayanti, 2016. Jurnal Ilmiah Manajemen Bisnis, 16(1), 45-58.

Puger Harjuno, 2018. (2018). PENGARUH KUALITAS PRODUK, PERSEPSI HARGA, DAN CITRA MEREK TERHADAP KEPUTUSAN PEMBELIAN MOTOR MATIC HONDA SCOOPY.

https://www.bps.go.id/ Diakses pada tanggal 24 Oktober 2018, pukul 17.53

https:// www.finance.detik.com/ diakses pada tanggal 24 Oktober 2018, pukul 10.03

https://www.merdeka.com/ Diakses pada tanggal 24 Oktober 2018, pukul 17.53 